\title{
Performing and Dying in the name of World Peace: From Metaphor to Real Life in Feminist Performance
}

\author{
Ahu Antmen \\ Marmara University, Istanbul, Turkey
}

\begin{abstract}
The paper presents an analysis of "Brides on Tour" undertaken by the Italian performance artists Pippa Bacca and Silvia Moro on International Women's Day $\left(8^{\text {th }}\right.$ March) in 2008 and considers it as much as a symbolic act of sacrifice, performing for global politics as potent subject and woman as victimized object of local 'petty crime'. A very important aspect of the performance is the way it blurs certain boundaries, as with feminist activity in general. In the performance, the writer detects a sense of solidarity by women for women on a global level, where the sacrifice reflected in the risk-taking aspect of hitchhiking symbolizes the past efforts of feminist activists who have at times put their lives in danger to better the living conditions of women through the ages and across nations.
\end{abstract}

[Keywords: Brides on Tour, Pippa Bacca, feminist, performance]

Italian performance artists Pippa Bacca and Silvia Moro departed from Milano on International Women's Day $\left(8^{\text {th }}\right.$ March) in 2008 to realize a performance that involved hitch-hiking, separately, through the Balkans and the Middle East. Aiming to meet people and listen to their stories of war and peace along a route that included some war-torn territory, their final destination was to be Tel Aviv. They called their performance "Brides on Tour" and wore white wedding dresses as a symbol of the marriage between different peoples and nations. These wedding dresses were to be exhibited as the residue of the performance, bearing all the traces of their journey. Silvia Moro reached Tel Aviv, finalizing her part of the performance. Pippa Bacca was raped and killed in Gebze, Turkey on the third week of the performance, after having hitchhiked through Italy, Slovenia, Croatia, Bosnia, Serbia and Bulgaria. Feminist activist groups and artists in Turkey issued statements of reaction, marched on walks of protest, organized exhibitions in Pippa Bacca's name to damn not only the rapist, but the whole culture of rape (incest, rape of single tourist women, intramarriage rape, etc.) in Turkey. The matter is now in the hands of the police, who have caught the felon, but are investigating further suspicion as to other men involved in the rape and murder.

An actual, as much as a symbolic act of sacrifice, entailing a hairbreadth's difference between woman, on the stage, performing for global politics as potent subject and woman as victimized object of local 'petty crime', the "Brides on Tour" performance, I believe, deserves a close investigation as an art performance, and particularly as an act of political activism, as it does as the event of a criminal offense. Actually, a very important aspect of the performance

\footnotetext{
Rupkatha Journal on Interdisciplinary Studies in Humanities

Volume 2, Number 1, Special Issue, Visual Arts

URL of the Issue: http://rupkatha.com/rupkathav2n1.php

PDF URL of the article: http://rupkatha.com/V2/n1/BridesonTourpippabacca.pdf

(C) www.rupkatha.com
} 
is the way it blurs certain boundaries, as with feminist activity in general. According to Val A. Walsh, feminism weakens traditional boundaries and demarcations, including subject boundaries (aesthetics/ethics/politics/therapy) and social boundaries (between the private and the public.) ${ }^{1}$ Not only the outcome, but also the whole idea around "Brides on Tour" contains questions about the general state of aesthetics (Has contemporary art become so obsessed with 'the real thing'? If so, can we say that genres such as reality tv and real life documentary have transformed the expectations of viewers of art and culture, and this has in effect been influential on artistic practice?); ethics (Where does individual and social responsibility begin and end on matters of global conflicts and war? Do individuals have the duty to be dutiful?); politics (Can anything be gained through political activism against war? Should art be used as a form of political activism? How can political art contribute to a cause?) ; and therapy (Can art change the world? Can artists heal the world?).

The most striking aspect of the performance is surely its naïveté in the face of global politics. But that naïveté is only one of the deliberate indications that signify the roles reflected on women's relations to global affairs. The departure date on $8^{\text {th }}$ March, known formally as International Working Woman's Day, is a day of global celebration for the political, economic and social achievements of women. It's hard not to notice that International Women's Day is becoming depoliticized in recent times, in (many) countries where capitalist consumer culture is an effective force on the media and visual culture. Now, when the world celebrates women on the $8^{\text {th }}$ of March, events such as the 1911 Triangle Shirtwaist Factory fire in New York City which resulted with the death of 140 women workers (coincidentally most of them Italian) working in poor conditions is rarely remembered as one of the foremost events that led to the date being celebrated as International Women's Day. ${ }^{2}$ Nor are the many other political struggles involving women's rights on an international scale. Looking from this perspective, the departure of "Brides on Tour" on the $8^{\text {th }}$ of March seems less as the prelude to a naïve hiking adventure than a conscious attempt at reminding the world of the true meaning of a global celebration day in the name of women. Thus we can read in the performance a sense of solidarity by women for women on a global level, where the sacrifice reflected in the risktaking aspect of hitchhiking symbolizes the past efforts of feminist activists who have at times put their lives in danger to better the living conditions of women through the ages and across nations.

Hitchhiking as art performance and political activity has its roots, no doubt, in the fading boundary of art and life especially since the 1960's, and more specifically since 1968 when, students and workers not only protested against 'the establishment' but the accepted premises of art, such as the material art object, the gallery and the museum, as a reflection of that establishment. ${ }^{3}$ This conceptual and ideological outlook on art practice entails the experience, rather than the representation of time and space, and thus performance is an ideal means to an end in materializing certain concepts. It is tragically ironic that Pippa Bacca's performance, as an ideal means to an end, literally came to mean her end as her act contained the risk of danger in all its possibility, yet it could be argued that it is exactly this reality principle -the 'anything could happen'- that establishes the "Brides on Tour" performance as a truly sincere political activity. 
The statement, issued by Moro and Bacca before their departure, is also a testament to their intrepid political action: "Hitchhiking" it reads, "is choosing to have faith in other human beings, and man, like a small god, rewards those who have faith in him." ${ }^{\prime 4}$ Trust in the other, in the possibility of individuals and cultures coming together, trust as a human factor and actually "breaking bread together" to prove these points was the underlying motivations for taking the risk of traveling through lands of conflicting cultures. ${ }^{5}$

Art, through acts of performance, has frequently been utilized as a tool for political activity. Furthermore, performance art has always been a preferred medium for woman artists because of its political aspect, its base, according to RoseLee Goldberg connected almost always to anarchic activity. ${ }^{6}$ An interesting early example that can be remembered as a link between anarchic activity, art, feminism and women's performance is feminist Mary Richardson's attack on Velazquez's "Rokeby Venus" in the National Gallery in London. One of a series of militant suffragist attacks on works of art and public buildings in London between 1912-1914, the attack, according to Lynda Nead, was presented to the nation's press by Mary Richardson as a "symbolic act" trying to destroy the picture of the most beautiful woman in mythological history as a protest against the Government destroying Emily Pankhurst, who she described as the most beautiful character in modern history. ${ }^{7}$ This example is significant because it shows that early feminist political activity spontaneously contained performance and acted out its political message, while later feminist artistic activity deliberately contained performance and acting out as an unavoidable part of its message. This was inevitable, since the message itself was about women gaining their own identity, represented in various ways through women's bodies and performance.

The "Brides on Tour" performance can be linked with the early feminist performance of the sixties and seventies especially in the reckless risk-taking performed by the artists themselves. What must be pointed out however is the changing scene of the performance: From art venue to real world territory, from metaphor to real life, the "Brides on Tour" left behind the blurred boundary between art and life, and crossed further into the war zone where the woman's body becomes not only a symbolic, but a real entity. In this sense it extends even the most notable of all 'real life' performance. We can remember Japanese artist Yoko Ono's "Cut Piece" (1964) in which members of the audience were invited to cut away the artist's clothes, or Serbian artist Marina Abramovic's "Rhythm O" (1974) when spectators were invited to do whatever they wanted to the artist for six hours, using instruments of pain and pleasure. "By the third hour" relates RoseLee Goldberg, "her clothes had been cut from her body with razor blades, her skin slashed; a loaded gun held to her head finally caused a fight between her tormentors, bringing the proceeding to an unnerving halt." ${ }^{8}$ French artist Gina Pane's "Autoportraits" (1973) on the other hand, involved self-inflicted wounds with a razor blade to her own body; the body being, according to the artist, "the irreducible core of the human being, its most fragile part. This is how it has always been, under all social systems, at any moment in history. And the wound is the memory of the body: it memorializes its fragility, its pain, thus its 'real' existence."

The 'real' aspect of all these performances is surely their most striking dimension, what sets these apart from real life however is that the setting is 
always in the framework of an art gallery or institution. This does not mean however that feminist art performance was restricted to an 'art setting'. We need only bring to mind performance pieces such as Austrian artist Valie Export's "Genital Panic" (1969), in which the artist entered a sex cinema in Munich wearing jeans with the crotch removed, and announced that real female genitals were available to do whatever the audience wanted. Luckily, she was armed with a machine gun! Valie Export's explanation about this performance piece gives us an insight into the motivations behind such work: "I moved down each row slowly, facing people. I did not move in an erotic way. I walked down each row, the gun I carried pointed at the heads of the people in the row behind. I was afraid and had no idea what people would do. As I moved from row to row, each row of people silently got up and left the theatre. Out of film context, it was a totally different way for them to connect with the particular erotic symbol."10 The "Brides on Tour", Pippa Bacca and Silvia Moro, had no gun on them for obvious reasons, or other protective weapon and no other 'safety belt' save for mobile phones when they left on the journey to promote world peace. This is why the "Brides on Tour" can be claimed to be a zenith of all the performances by woman artists that have involved risk-taking, pain and total submission to the other: it is a performance piece of ultimate real time, real space and real encounter. In this sense, the naïveté involved in the "Brides on Tour" performance is surely an act that signifies, and defies the passive role reflected upon women in most parts of the world, another topic that comes to mind in relation to women performing on a global arena.

The tragic outcome of the "Brides on Tour" performance also brings to mind Cuban-American artist Ana Mendieta's "Rape Scene" (1973), which was based on a series of performance pieces that referred to the death of a university student who had been raped and murdered at the lowa University campus. Photographs of Mendieta performing the piece in nature bring to mind the conditions in which the body of Pippa Bacca was found. The resemblance of the images -one, a rape scene enacted by a performance artist, the other a rape scene experienced by a performance artist during her performance piece- is a sure sign of how performance art by feminist artists has been carried out to the very extreme: Thus the price of Pippa Bacca's performance has been no less than the ultimate end. In an interview with the Los Angeles Times, Pippa Bacca's mother explains that Pippa's first walking journey was when she was twelve years old, through pilgrimage roads to Santiago de Compostela in Spain. ${ }^{11}$ According to Umberto Eco, not only pilgrimage to the Santiago de Compostela but going on a trip anywhere in the Middle Ages was synonymous with "preparing one's will", as journeys could lead to "coming across bandits, unfettered gangs or wild animals." ${ }^{2}$ Bacca and Moro were surely aware that in our day, maybe not wild animals but other danger could be roaming round the corner.

What is the real outcome of the performance "Brides on Tour"? What can we learn from it, what does it really tell us? Is it just a criminal affair, a stroke of bad luck? Or does this long journey, through the Balkans and the Middle East imply further meanings about women taking social responsibility in the world of global politics? Performance art based on women's issues contributed, and still contributes to the feminist cause, but can the same activist methods also contribute to raise awareness and actually change mentalities related to other 
political issues? Yes, that naïve question: Can art change the world? Silvia Moro and Pippa Bacca seemed to think so. To try and show that art could change the world and women could make a difference! The purpose was to exhibit those white wedding dresses, smeared with the traces of their journey, after having proved that "marriage between peoples" was indeed possible. I don't know if any curator will one day want to show Pippa Bacca's wedding dress, but the question remains as to if her death -during a performance in the name of world peace- will be remembered as more than just a performance accident.

\section{References}

Eco, Umberto. Günlük Yaşamdan Sanata. translated from Italian to Turkish by Kemal Atakay. Istanbul: Adam Yayınları, 1991.

Goldberg, RoseLee. Performance Art from Futurism to the Present. London: Thames and Hudson, 1993.

Nead, Lynda. The Female Nude-Art, Obscenity and Sexuality. London and New York: Routledge, 1992.

Reckitt, Helena and Peggy Phelan. Art and Feminism. London\&New York: Phaidon Press Limited, 2001

Val A. Walsh. "Eyewitnesses, not spectators-activists, not academics: feminist pedagogy and women's creativity". New Feminist Art Criticism. Ed. Katy Deepwell. Manchester and New York: Manchester University Press, 1995.

\section{Notes}

1 Val A. Walsh. "Eyewitnesses, not spectators-activists, not academics: feminist pedagogy and women's creativity". New Feminist Art Criticism. Ed. Katy Deepwell. (Manchester and New York: Manchester University Press, 1995), 56.

${ }^{2}$ For details see http://www.internationalwomensday.com/about.asp (accessed February 22, 2009).

${ }^{3}$ RoseLee Goldberg. Performance art From Futurism to the Present (London: Thames and Hudson, 1993), 152.

${ }^{4}$ The statement was issued on the Website address bridesontour.fotoup.net, but the address no longer exists due to the murder investigation.

${ }^{5}$ In her article "Performance Artist Killed on Peace Trip is Mourned" (New York Times, April 19, 2008) Elisabetta Povoledo discusses the implications of the "Brides on Tour" performance with Silvia Moro. http://nytimes.com/2008/04/19/theater/19peac.html (accessed February 22, 2009).

${ }_{7}^{6}$ Goldberg, Performance Art From Futurism to the Present, 9.

7 Lynda Nead. The Female Nude-Art, Obscenity and Sexuality (London\&New York: Routledge, 1992), 35, 42.

${ }^{8}$ Goldberg, Performance Art From Futurism to the Present, 165.

${ }^{9}$ Helena Reckitt and Peggy Phelan. Art and Feminism. (London\&New York: Phaidon Press Limited, 2001), 101. 
${ }^{10}$ Reckitt and Phelan. Art and Feminism, 97.

${ }^{11}$ In her article "Italian Pippa Bacca's fatal journey" (Los Angeles Times, May 31, 2008) Laura King quotes Pippa Bacca's mother Elena Manzoni, who says she hitchhiked a lot because it is the best way to get to know people and that her daughter got this habit from her. http://articles.latimes.com /2008/may/31/world/fg-pippa31 (accessed February 23, 2009).

${ }_{12}$ Umberto Eco. Günlük Yaşamdan Sanata. (İstanbul: Adam Yayınları, 1991), 23.

Ahu Antmen is Assistant Professor at Marmara University Faculty of Fine Arts in Istanbul, Turkey. Email: aantmen@doruk.net.tr 